\title{
Managing New Ventures
}

Abstract The creation of new ventures and growing them into wellestablished organizations is the key purpose of managing new ventures. This chapter explains the 10 most essential subtopics for managing new ventures (Shepherd et al. in Journal of Management 47:11-42, 2021): (1) lead founder, (2) founding team, (3) social relationships, (4) cognitions, (5) emergent organizing, (6) new venture strategy, (7) organizational emergence, (8) new venture legitimacy, (9) founder exit, and (10) entrepreneurial environment. This chapter ties these "managing" subtopics into the three major stages of the entrepreneurial process- $\mathrm{CO}^{-}$ creating, organizing, and performing. The framework provides a cohesive story of managing new ventures.

Once an entrepreneur forms an opportunity belief (Chapter 1), the entrepreneur can exploit the potential opportunity through an existing organization or create a new organization. In this chapter (and the book more generally), we are focused on new venture creation. New venture creation is important. New ventures (1) are the source of most new jobs generated in an economy; (2) create new industries and markets; (3) develop and introduce innovative products and services; and (4) provide new solutions to economic, social, and environmental problems.

This chapter is based on Shepherd et al. (2021). The assertions that we make in this chapter are justified, cited, and referenced in Shepherd et al. (2021).

(C) The Author(s) 2021

D. A. Shepherd and H. Patzelt, Entrepreneurial Strategy, https://doi.org/10.1007/978-3-030-78935-0_4 
However, most management research has assumed a well-established organization as the starting point of their theorizing. This management research has focused on explaining differences among organizations regarding various attributes, forms, and outcomes. Research on new venture creation and management to produce well-established organizations has increased our understanding of the antecedents of many assumptions prevalent in extant management research.

However, current research does not provide an accumulated body of knowledge to connect the creation of new ventures to their development into well-established organizations. Therefore, this chapter builds on a review paper on starting a new organization, which organizes the information on this process provided by extant research into an overarching framework (Shepherd et al., 2021). In conducting a systematic review of the literature, Shepherd et al. (2021) inductively categorized papers primarily on the topic of new ventures into 10 categories: (1) lead founder, (2) founding team, (3) social relationships, (4) cognitions, (5) emergent organizing, (6) new venture strategy, (7) organizational emergence, (8) new venture legitimacy, (9) founder exit, and (10) entrepreneurial environment. We present these categories as an overarching framework in Fig. 5.1.

As illustrated in Fig. 4.1, the major stages of the overarching framework are (1) co-creating a startup, (2) organizing a startup, and (3) performing a startup. The co-creating stage is typically initiated by a lead entrepreneur forming a founding team. The lead entrepreneur and the entrepreneurial team use social relationships and cognitions to coconstruct the new venture's potential opportunity with its community of inquiry (see Chapters 2 and 3). The community of inquiry is an informal body of (potential) stakeholders with a shared interest in the new venture's potential opportunity. The organizing stage involves the new venture establishing operations as well as formulating and enacting a strategy. In this stage, the entrepreneur attempts to establish processes and systems that can facilitate legitimacy, organizational emergence, and founder exit. The performing stage builds on the previous stages to generate outcomes. These new venture outcomes feed back into the other stages of the model. All stages of the new venture-management process are influenced by and influence the external environment. 


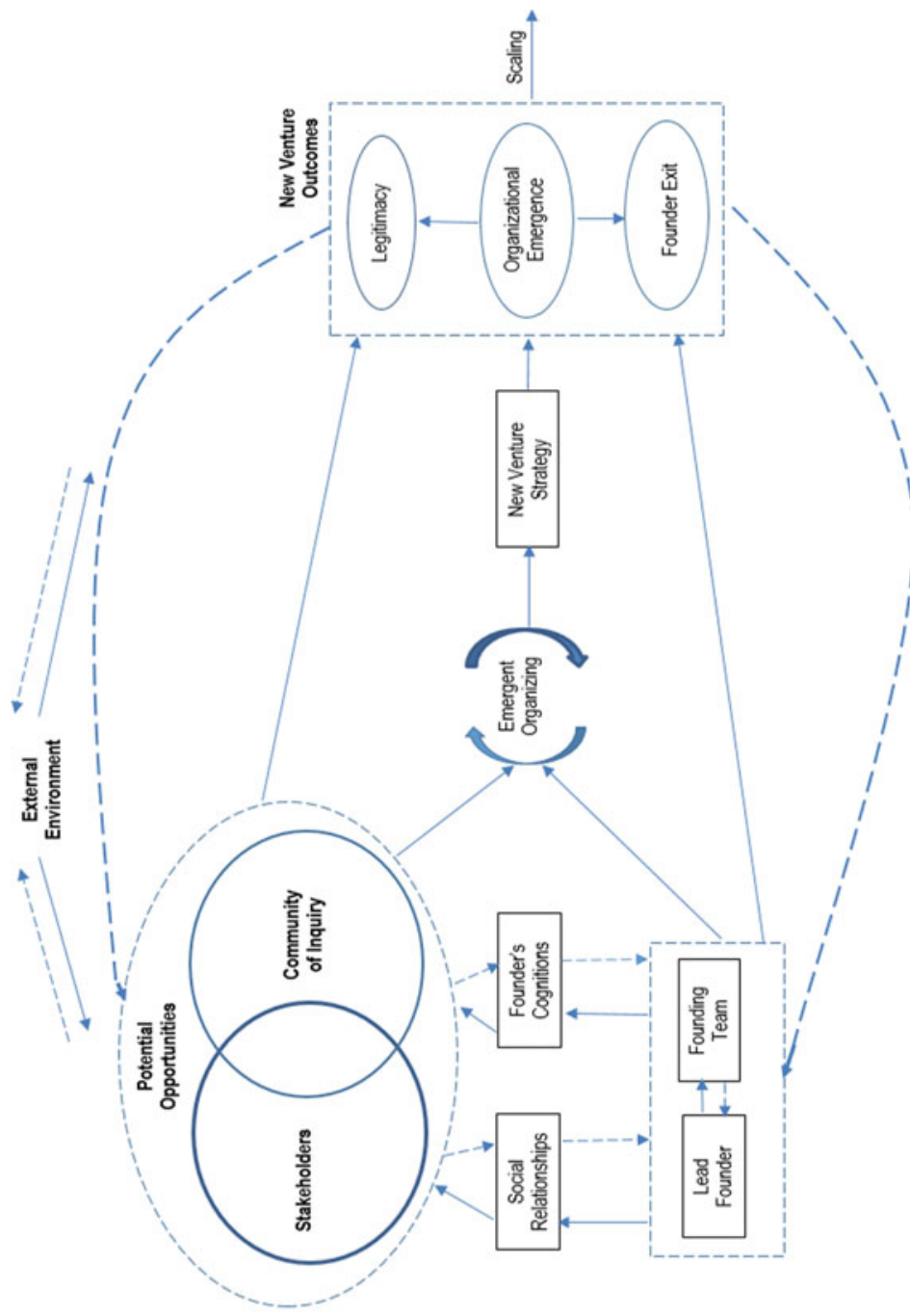




\section{Co-creating a Startup Venture}

\section{Lead Founder and Starting a New Venture}

A founder is a person who creates a new venture-that is, brings into existence a new organization. Even in a new venture created by a team, individual founder attributes are important for explaining new venture creation. The lead founder is the founding team member most responsible for managing the startup process (if there is only one person, he or she is solely responsible for the early stages of new venture creation; there is also the possibility of two or more lead entrepreneurs in a venture). Founders differ in their experience, employment positions before new venture creation, entrepreneurial imaginativeness, motivation, emotional responses, and enduring characteristics. These differences among founders influence new venture creation.

First, founders vary in their experience, which impacts the startup process. Specifically, a founder with managerial experience - a founder who previously operated a business - has an advantage in new venture creation, especially in pursuing opportunities in highly dynamic external environments. In contrast, a founder with industry experience- $\mathrm{a}$ founder who previously worked in the same industry as his or her new venturehas an advantage in pursuing opportunities in less dynamic external environments. Entrepreneurial experience-when a founder has previously founded one or several ventures-is important in contexts where entrepreneurs need to make quick decisions to commit their ventures to action. More generally, new ventures created by founders with more entrepreneurial experience perform better than those created by founders with less entrepreneurial experience. Interestingly, prior entrepreneurial experience benefits new ventures regardless of whether that experience was a success or a failure.

However, a founder's experience is not always a blessing for his or her new venture. For example, a founder's experience with a particular product market, geographic market, or resource can focus his or her attention on those domains, causing cognitive or attentional blindness to other opportunities and threats sourced beyond those domains (see Chapter 1). Similarly, while individuals returning from another country to their home country to start a business have different experience from those who have never left their home country, entrepreneurs with this experience abroad tend to complete the first stage of the entrepreneurial process more slowly. That is, those with experience abroad advance from 
conceptualizing a potential idea to launching a new venture more slowly than individuals without such experience (Qin et al., 2017).

Second, employees can create new ventures. Employee entrepreneurship involves "the intra-industry founding of a new venture by an individual who previously worked for an incumbent firm [a firm in the same industry as the new venture]" (Ganco, 2013, p. 666). A new venture can benefit from employee entrepreneurship when there is considerable overlap between the knowledge its founder acquired from his or her previous employer and the new venture's knowledge domain. It seems that the greater the overlap, the more knowledge the entrepreneur can transfer to the new venture. For example, the entrepreneur may transfer effective routines and draw on knowledge gained at his or her previous employer to recognize subsequent potential opportunities. However, although it seems that star performers would leave their jobs to found new ventures as a means to make the most of their human capital, it is not so simple. The creation of a new venture by a star performer depends on the star's compensation at work. High-earning individuals are less likely to leave their jobs than low earners. Still, they are more likely to leave when their employers have low compensation-dispersion systems. If they leave their current jobs, these star performers are more likely to start a new venture, whereas non-star workers are more likely to seek employment elsewhere (Campbell et al., 2012; Carnahan et al., 2012). Furthermore, those leaving employment are more likely to start a new venture than seek employment elsewhere when they have more complex knowledge (Ganco, 2013). Knowledge is complex when there are many interdependencies between its components.

Third, people with entrepreneurial imaginativeness are more likely to create a new venture. Entrepreneurial imaginativeness refers to "a cognitive skill that combines the ability of imagination with the knowledge needed to stimulate various task-related scenarios in entrepreneurship" (Kier \& McMullen, 2018, p. 2266). This cognitive skill is useful in new venture creation because it stimulates the creativity necessary to identify or construct potential opportunities. Potential opportunities can then be tested and refined as the basis for a new venture (see Chapters 2 and $3)$. Some of the knowledge needed to create various entrepreneurialimaginativeness scenarios likely comes from the managerial, industry, entrepreneurial, and employment experience detailed above.

Fourth, an individual needs to be motivated to create a new venture. This motivation for new venture creation can be manifest in a founder's 
identity and passion. Founders with a higher entrepreneurial identity aspiration- "a possible but unrealized future entrepreneurial self"-engage in more nascent entrepreneurial behaviors, particularly founders who have prior startup experience compared to those who lack such experience (Farmer et al., 2011, p. 246). There are three ideal types of entrepreneurial social identity, which help explain those who create new ventures (Fauchart \& Gruber, 2011):

(a) The Darwinian identity reflects founders who consider themselves unique, put their self-interest at the core of the new venture, pursue private goals, and use a conventional business logic to run the new venture; (b) the Communitarian identity reflects founders who focus their actions based on a proximal social group and have a community-driven logic; and (c) the Missionary identity reflects founders who have a highly inclusive notion of stakeholders, focus on the society-at-large, and have a mission-driven logic. (Shepherd et al., 2021, pp. 15-16)

Founders can also have passion that motivates new venture creation. Entrepreneurial passion is an "intense positive inclination towards entrepreneurial activities salient to an individual's identity.... Passion [is not conceptualized] as a trait but rather as an affective and motivational phenomenon that an entrepreneur experiences when engaging in identity relevant activities" (Murnieks et al., 2016, p. 470). This passion motivates an individual to perform new venture-creation tasks. Indeed, entrepreneurial passion can increase an individual's entrepreneurial selfefficacy, strengthening his or her intention to start a new venture.

Fifth, positive affect can positively influence an individual to new venture creation. Specifically, positive dispositional affect facilitates creativity, and creativity generates innovative activities useful in the new venture-creation process. The positive relationships between positive affect and creativity and between creativity and innovation radicalness are strengthened in more dynamic environments (Baron \& Tang, 2011). Positive dispositional affect refers to a founder's general tendency to experience positive emotions, such as enthusiasm and excitement. Dispositional affect is different from state affect; state affect is influenced by current conditions. Dispositional affect is relatively stable across time, contexts, and situations. However, a founder's positive dispositional affect may not always lead to positive venture outcomes. For example, one study proposed that while increases in positive dispositional affect 
improve entrepreneurs' opportunity recognition, opportunity evaluation, and entrepreneurial decision making, they only do so to a certain point, after which further increases in positive dispositional affect may hamper performance on these activities (Baron et al., 2012).

Finally, individuals' personalities influence who starts up a new venture. Specifically, the positive psychological traits of hope, optimism, and resilience are positively associated with founders' transformational leadership, which in turn facilitates new venture performance. The positive psychological trait of hope refers to the belief that one has a path to a desired outcome and believes one has the agency to progress down that path. Optimism refers to a generalized belief that positive outcomes will materialize. Resilience refers to maintaining positive functioning while facing adverse events. These positive psychological traits can lead to transformational leadership, which can in turn enhance new venture performance through the following mechanisms: (1) idealized influence, or when a founder provides an example that followers try to emulate; (2) inspirational motivation, or when a founder provides a clear vision of a positive future that motivates followers; (3) intellectual stimulation, or when a founder helps followers make the most of their potential; and (4) individualized consideration, or when a founder supports followers' needs for personal growth (Peterson et al., 2009). Bundling founders' personalities with their resources and the environment helps explain the new venture-creation process. For example, founders' tendencies to value "change, the new, and the different" (i.e., novelty) can enhance new venture performance, especially for ventures that are younger and smaller (Ling et al., 2007, p. 679).

\section{Founding Team and Starting a New Venture}

A founding team is a collective that creates a new venture. Founding teams differ in their experience, diversity, presence of prior shared experience, and structural form, which impact new venture management.

First, founding teams differ in the level and nature of their experience. Founding teams' experience can influence new venture performance. For example, for newly created venture capital firms, founding teams that are more experienced in venture capital, senior management, and consulting are more successful than their more inexperienced counterparts (Walske \& Zacharakis, 2009). Moreover, in assessing new venture teams, senior venture capitalists emphasize, in order of importance, teams' industry 
experience, management education, and leadership experience (Franke et al., 2006). Indeed, founding teams' entrepreneurial and management experience are important because they enable these teams to identify more opportunities. Additionally, teams with greater competence in financial management-namely, skills, experience, and ability to manage monetary constraints-are better able to create and grow new ventures. Furthermore, new venture teams with greater technological experience make the most of their diverse industry-experience and external sources of knowledge to identify a greater variety of potential opportunities.

Second, founding teams' diversity facilitates new venture creation. For example, teams diverse in educational backgrounds benefit new ventures. Indeed, venture capitalists value educational heterogeneity, with the proviso that at least one of the members on a team has an education in management. Despite the importance of diversity within founding teams, it appears that founders' biased decision making (e.g., overoptimism and self-serving attributions) leads them to choose cofounders similar to themselves, thus creating relatively homogenous founding teams. However, we also note that more diversity in founding teams might not always benefit new ventures. For example, the dispersion of a founding team's cognitive ability has an inverted U-shaped relationship with startup performance. That is, teams with members of both high and low ability outperform teams in which all members have low ability or all members have high ability because some entrepreneurial tasks require high ability (e.g., opportunity recognition and problem solving) while other tasks are better performed by lower-ability team members (e.g., execution-oriented tasks) (Hoogendoorn et al., 2017). While diversity enhances performance in competitive contexts, it does not appear to do so in cooperative contexts or in pursuit of innovation strategies. In contexts that reward cooperation and innovation, technically focused management teams perform better than functionally diverse teams (Eesley et al., 2014).

Finally, founding team members with prior shared experience can manage more of the challenges in new ventures. Teams in which some of the members have previously worked together in the same company have shared knowledge. This shared knowledge promotes a shared understanding that facilitates implementation speed and enhances new venture performance. However, this benefit from prior shared experience within a founding team is diminished when that shared experience is for a task or industry different from those of the new venture. Moreover, the benefits of teams' prior shared experience diminish over time as founding 
teams begin to generate their own shared experience in their current new ventures. Relatedly, founding teams with shared prior experience can create more internally consistent human-resource value systems for their new ventures that facilitate shared collective perceptions, attitudes, and behaviors among new venture members. Founding teams with prior shared experience are also more likely to pursue exploration strategies. At the same time, those with members who have worked in diverse companies are more likely to engage in explorative activities. However, research has also shown that teams with prior shared experience and heterogeneous experience show the highest growth (Beckman, 2006).

One potential mechanism underlying the benefits of a team's prior shared experience is a transactive memory system. A transactive memory system is a shared understanding of which team members have specific expertise that the team can call on when needed-that is, knowing "who knows what" (Zheng, 2012). A founding team's transactive memory system can enhance new venture performance, especially when there is task similarity, task relatedness related, and intrateam trust. A founding team's transactive memory system can also lead the new venture to develop an entrepreneurial orientation. Entrepreneurial orientation refers to a new venture's strategic orientation involving the propensity to be innovative, risk taking, and proactive. The trust between founding team members, the organizational structure's organic nature, and the environment's dynamism magnify the positive relationship between a founding team's transactive memory system and the respective venture's entrepreneurial orientation.

\section{Social Relationships and Starting a New Venture}

A socialvelationship is a positive interpersonal relationship between two or more people. Social relationships are reflected in (1) a founder's social network, (2) a founder's social capital, (3) a founder's use of his or her network to access intangible resources, and (4) a new venture's interpersonal interactions.

First, founders' relationships are embedded in social networks, which vary across founders and founding teams. Founders' networks involve referrers-individuals or organizations that connect entrepreneurs to potential resource providers. Potential resource providers are the owners of resources that new ventures need. Specifically, a venture is more likely to obtain the resources it needs when (1) there is a strong relationship 
between the referrer and the resource owner, especially when there is a strong relationship between the founder and the referrer, and (2) both the referrer and the resource owner have considerable prior knowledge of the venture's technology or product. Interestingly, the resource owner's prior knowledge of the venture's technology or product compensates for weak relationships between the founder and the referrer and between the referrer and the resource owner-the relationship facilitates action.

It is possible to consider entrepreneurial networking as more than just a facilitator of entrepreneurial action. Specifically, entrepreneurial networking is intentional behavior under high uncertainty. It includes assessing the use of one's existing network of relationships, negotiating precommitments with stakeholders, and continually changing the set of relationships supporting the focal venture. Although it would seem that the larger a founder's network, the better it is for his or her venture, there are diminishing returns to accessing funding, information, and business contacts from increases in network size. Over and above a network's size, relationship quality, trust, and commitment help a new venture access resources under favorable terms. Indeed, both the size of a social network and the strength of the relationship between founders and potential funders relate positively to progress in new venture creation. Also, founders' networks that are heterogeneous and high in status generate benefits for their new ventures. A heterogeneous network is a set of relationships that provides a new venture access to diverse information and varied resources. A high-status network is a set of relationships that signals a new venture's quality to others.

Second, new ventures can benefit from their founders' social capital. This social capital can have a variety of sources. Social capital refers to the goodwill created through social relationships, and some founders have more social capital than other founders. For example, founders who are returning migrants or have experience with multinational enterprises typically have higher social capital than founders without such global-market experience. Moreover, entrepreneurs have higher social capital with their families than with other groups and individuals. Therefore, family involvement in the governance of early-stage new ventures is associated with a higher probability of raising debt funding and with increasing the amount of funding founders can obtain. However, founders often seek initial funding from their families rather than from other investors when they anticipate low family interference in their businesses. This funding strategy shows that there are benefits (e.g., easier access to capital) and costs (e.g., 
potential interference) that arise from relying on family relationships when creating a new venture. Indeed, when entrepreneurs involve their families to gain financial capital, the scope of their startup activities is narrowed. In contrast, when entrepreneurs involve their families to access social capital, the scope of their startup activities is broadened, and even more so when their families are highly cohesive (Edelman et al., 2016).

Third, founders' social relationships can provide new ventures intangible resources. Close relationships can provide founders entrepreneurial inspiration, thereby enhancing new ventures' chances of survival. This benefit of founders' entrepreneurial inspiration is magnified for those who take over an existing business, invest considerable time in their ventures, and/or have low entrepreneurship experience. Social relationships can also be a source of guidance as founders often use outsiders' assistance when starting their ventures. This guidance increases long-term growth to a point, after which more guided preparation reduces long-term growth. A similar form of guidance is when venture advocates help founders. Venture advocates are local potential stakeholders who assist founders in their new ventures' developmental stages, facilitating new ventures' launch and increasing their survival chances.

Finally, boards of directors can generate benefits for new ventures. Specifically, a new venture can establish a diverse alliance portfolio more quickly when its board of directors is heterogeneous (i.e., directors' backgrounds and networks are diverse), multiplex (i.e., directors have multiple types of relationships), and symmetrical (i.e., there is an even distribution of influence within the board of directors) (Beckman et al., 2014). Moreover, a new venture can benefit from its board of directors expanding the founding team's network. This enhanced network of the board and founding team can generate relational pluralism. Relational pluralism refers to a new venture's reliance on others to derive meaning and the impetus for action. However, when central investors dominate a board, the benefits of board members' social relationships for the focal new venture are undermined.

\section{Cognitions and Starting a New Venture}

Founders' cognitions are the mental processes underlying the coconstruction of potential opportunities to start and manage a new venture. Founders' cognitions can be driven by their enduring characteristics and by their current situation. In turn, these cognitions can lead 
to biased decision making, enhanced identification of potential opportunities, and increased intentions to engage in entrepreneurial action.

First, founders' enduring characteristics drive their cognitions about their new ventures. One enduring characteristic of founders is the intelligence critical for new venture success, called successful intelligence. When combined with entrepreneurial self-efficacy, successful intelligence can lead to quick decisions and actions that promote new venture performance. This intelligence for new venture progress involves three different types of intelligence: (1) practical intelligence relates to founders' skills, dispositions, and tacit knowledge and the application of them to solve everyday problems; (2) analytical intelligence is founders' capacity to learn quickly, remember, and retrieve information; and (3) creative intelligence is reflected in founders' generation of high-quality novel ideas to meet current needs (Baum \& Bird, 2010).

Cognitive style is another enduring attribute of founders that influences their cognitions about their new ventures. Cognitive style is a "higher-order heuristic that individuals employ when they approach, frame and solve problems" (Brigham et al., 2007, p. 31). People with different cognitive styles are better suited for different entrepreneurial tasks. Founders with a more intuitive cognitive style are more likely to observe signals and process information synthetically and holistically. These intuitive entrepreneurs report high confidence in identifying and recognizing opportunities. In contrast, founders with an analytical cognitive style process information in a more linear and sequential way. Those with an analytical cognitive style have greater confidence in assessing, evaluating, planning, and marshaling a new venture's resources (Kickul et al., 2009).

Second, founders' thinking about the future to plan the next steps for the new venture can enhance venture performance. Founders who engage in formal business planning facilitate entrepreneurial judgment because doing so helps founders ( 1 ) be more selective in their decision making to focus on a smaller set of new venture-success factors, (2) become more decisive to quickly make venturing decisions, and (3) have a greater conviction in their entrepreneurial judgment.

Third, founders' cognitions can lead to biased decision making. Specifically, new venture managers who are founders are likely to be more overconfident than non-founder new venture managers. Overconfidence refers to an individual's overestimation of his or her ability to deliver positive outcomes and is often based on this individual not knowing what he 
or she does not know. Founders' overconfidence can be detrimental to new venture progress. Founders are also often overly optimistic when forecasting their ventures' survival chances. While confidence in one's capabilities to successfully perform entrepreneurial tasks helps explain who creates new ventures, it can also lead to ventures' downfall.

Founders can also escalate commitment (through additional investments of money, time, and other resources) to a venture on a failing course of action, which is a biased decision. For example, while fear leads founding teams to quit their failing ventures, hope drives founding teams to escalate their commitment to such ventures. Interestingly, when founders feel both hope and fear, hope seems to "trump" fear, leading founding teams to escalate commitment to failing ventures. Escalating commitment to a failing venture can make failure more costly for the founder (and other stakeholders) than it needs to be.

Fourth, identification of potential opportunities is a key application of entrepreneurial cognitions. Without a perception of an opportunity, an individual is unlikely to start a new venture regardless of the external environment's objective attractiveness. Perceptions of opportunities involve the following stages (of a structuration process): (1) opportunity emergence, in which an opportunity forms through the interaction of an entrepreneur and a community of inquiry (see Chapter 2); (2) opportunity objectification, in which the entrepreneur begins to see the opportunity idea as an entity outside his or her mind; (3) opportunity enactment, in which a new venture is established, such as when a new venture emerges to deliver its first product or service; and (4) opportunity abandonment, in which the entrepreneur decides to terminate the potential opportunity.

This structuration approach to a potential opportunity depends on others' inputs into the new venture process (see Chapter 2). Who those others are likely impacts the cognitive process. For example, socially isolated founders tend to perceive potential opportunities more abstractly. When founders perceive potential opportunities more abstractly, they are less likely to create a new venture. Of course, founders perceive not only opportunities but also threats to their new ventures. Threats can cause stress, leading founders to engage in avoidance or active coping. Avoidance coping involves temporarily withdrawing from a situation appraised as threatening. Active coping involves directly addressing a threat through problem solving. Avoidance coping by itself or with active coping can help founders improve their psychological well-being (Uy et al., 2013). 
Finally, individuals' cognitions can involve the intention to start a new venture. An entrepreneurial intention involves an individual's commitment to new venture-creation activities, which drives his or her investments of time, effort, and other resources into startup activities. Founders' attitudes toward new venture creation drive their entrepreneurial intentions. These attitudes are perceptions of the desirability of taking action, the perceived feasibility of successfully undertaking the action, and subjective norms (i.e., the opinions of important social others about the focal action).

Individuals use their attitudes to interpret information about the environment to determine their entrepreneurial intentions. For example, attending an entrepreneurship program raises science and engineering students' intentions to start a new venture (Souitaris et al., 2007). Additionally, as founders perceive greater market heterogeneity, their entrepreneurial intentions strengthen because broader and more diverse markets provide potential opportunities for those who have a strong entrepreneurial orientation toward creating value. Indeed, founders' belief that they will achieve new venture success increases for those with a strong motivation to start a new venture, which is reinforced by decisionmaking expertise. While founders' motivation for starting a new venture can lead to new venture success, prosocial motivation appears to slow venture emergence through obstructing the assembly of critical resources, delaying the new venture's first sale, and making it more difficult to raise equity funding, and so on. Prosocial motivation is the desire to expend effort and other resources to pursue potential opportunities to help others.

\section{Organizing the Startup of a New Venture}

\section{Emergent Organizing}

Emergent organizing involves developing processes for engaging in activities and making connections to enhance ventures' operational reliability and effectiveness. Emergent organizing involves improvisation and engagement as well as different organizing modes, and it reflects founders' decision-making logic.

First, founders engage in actions to create new ventures, such as improvisation. Improvisation involves the fusion of design (e.g., planning) and novel action and may provide the initial inspiration for a new venture. 
One study found that founders' improvisational behaviors enhance new venture performance for those with high entrepreneurial self-efficacy but dampen new venture performance for those with low entrepreneurial self-efficacy. Over and above improvisation, there are other important activities involved in the startup process focused on four key business functions: (1) human relations, (2) marketing (including sales and public relations), (3) administration, and (4) environmental monitoring. One study found that founders allocate a significant amount of their time to exchanging information and opinions ( 36 percent of their work time) and engaging in more analytical and conceptual work (26 percent of their work time) (Mueller et al., 2012).

Second, different modes of organizing facilitate organizational emergence. There are three general modes of organizing: (1) vision for identifying potential opportunities, (2) strategic organizing for making major decisions, and (3) tactical organizing for implementing behaviors. Interestingly, an emergence event is initiated by a change in tactical organizing, which stimulates strategic organizing and generates a shift in vision (Lichtenstein et al., 2006).

Finally, founders' logic can influence organizational emergence. Specifically, expert founders appear to use an effectual logic. There are four primary principles of an effectual logic: (1) The affordable loss principle highlights how entrepreneurs evaluate opportunity pursuit based on how much they can afford to lose by taking this entrepreneurial action. (2) The alliance principle highlights how founders enter into strategic alliances to gain new stakeholders' precommitments. (3) The contingency principle highlights how founders remain open to unexpected events and exploit them as an opportunity. (4) The control principle highlights how founders take stock of what they have and create possible ends from these known means (Sarasvathy, 2001). These effectuation principles represent founders' responses to the recognition that while there is environmental uncertainty, they control their new ventures' ability to respond to external changes. Founders are more likely to use the principles of an effectual logic when they come from a career that involved investing and when they are experts than when they have less investing experience and are novices.

Moreover, effectuation involves taking action to secure the precommitments of potential stakeholders. These stakeholder commitments provide new ventures with resources and legitimacy. To gain the precommitments of stakeholders, founders can use boundary objects (see Chapter 3 ). 
Boundary objects are material artifacts that symbolize a founder's beliefs and values (e.g., an engineering drawing or a project timeline) and the basis for shared practice between the founder and his or her community of inquiry (Chapter 3 ). Boundary objects help founders connect loosely coupled potential stakeholders across multiple domains for their new ventures' benefit. Therefore, founders' creation and use of boundary objects to share, frame, and interact with potential stakeholders are critical for new venture emergence.

\section{Crafting a New Venture Strategy}

New venture strategy refers to the formulation, decision, and enactment of a particular vision and position within the competitive landscape. A new venture strategy is reflected in a venture's business model, which describes the envisioned venture and its functioning to achieve its goals. A new venture strategy involves planning, diversification, entry mode, and innovativeness.

First, planning impacts the success of starting up of new ventures. Completing a formal plan improves new venture performance in terms of early-stage profitability, employment growth, and survival (when the plan is formed before the focal venture engages with potential stakeholders and conducts other organizing activities). Founders who are better educated and oriented toward growth, innovation, and external finance are more likely to plan. The benefits of different types of planning depend on the nature of a new venture's external environment. Specifically, in highly dynamic environments, new ventures benefit from planning that is selective and quick. In contrast, in less dynamic environments, new ventures benefit from taking more time to complete the planning task.

Also, not all plans are formal. For example, founders' use of action plans magnifies the impact of entrepreneurial-goal intentions (i.e., what founders intend for their new ventures) on venture creation (Gielnik et al., 2014). Action plans are mental maps of the steps needed to move from the current situation to the desired goal. These action plans can dampen the negative impact of unfounded imagined futures on venture creation by compensating for the motivational drain of such positive fantasies.

Second, diversification can affect new venture survival and efficiency. For example, one study found that the diversification of nonprofit new ventures through a broad scope of products and services within and across industries (Tanriverdi \& Lee, 2008) increases these ventures' chances of 
survival. However, these increased survival chances can come at the cost of lower organizational efficiency.

Third, a founder can pursue subsequent opportunities via one of two entry modes - within his or her existing venture (de alio venture) or with a new venture (de novo venture). Both de alio and de novo ventures represent entrepreneurial action, but only the latter leads to a new independent venture. Habitual founders - founders with prior startup experience-are more likely to create a new independent venture to pursue new opportunities. In contrast, novice founders, or founders with no prior startup experience, are more likely to pursue potential opportunities within their existing ventures. Portfolio entrepreneurs are founders who concurrently pursue two or more opportunities. Founders who are more educated, have more relationships with government support agencies, more frequently use their business networks, and have prior startup experience are more likely to become portfolio entrepreneurs. Founders who are more educated, younger, have greater risk-taking prosperity, and are more inventive are more likely to enter a new market by starting an independent venture (than by acquiring an existing firm).

Finally, a new venture strategy can promote innovativeness, thereby impacting new venture performance. The nature of the relationship between a new venture strategy, innovation, and performance is not initially obvious. On the one hand, we would expect a new venture's innovativeness to generate benefits for the venture, such as market power, cost efficiency, and capabilities like absorptive capacity. On the other hand, a new venture's innovativeness increases the liabilities associated with newness, which increase its chances of failure. Indeed, in a study of Finnish startups, innovativeness reduced new ventures' survival chances, and founders' preferences for risk magnified this negative relationship (Hyytinen et al., 2015).

Furthermore, new ventures can tap into external knowledge as a source of innovation. Indeed, open innovation is about "harnessing knowledge flows across firm boundaries" (Greul et al., 2018, p. 392). New ventures can benefit from open innovation by using such knowledge flows to build their capabilities. Still, they need to recognize that there are risks associated with such openness to the crowd. Interestingly, user entrepreneurs are more likely to allow knowledge flows outside of their ventures without being compensated for this knowledge. User entrepreneurs have personal experience and derive personal benefits from using the products or services that their new ventures offer. Some individuals who create a 
new venture are called accidental entrepreneurs. Accidental entrepreneurs happen upon an idea for a new venture due to their personal use of a product or service. Like user entrepreneurs, accidental entrepreneurs are more likely to allow knowledge to flow outside their new ventures to others without collecting revenues.

\section{Facilitating Organizational Emergence}

Organizational emergence refers to progress in the steps toward creating a new organization. Organizational emergence arises from the completion of new venture-creation activities. A new venture emerges along with four properties: (1) intentionality, which is the founder's purposeful investment of resources for creating a new venture; (2) resources, which combine as the building blocks of an organization; (3) boundary, which creates a formalized space for the new venture that separates it from other entities; and (4) exchange, which involves exchanging information and other resources across the emerging new venture's boundary (Katz \& Gartner, 1988). By engaging in activities that facilitate these emergence properties, founders can establish new ventures with capabilities and stakeholder support to deal with the ventures' liabilities of newness. Counterintuitively, one study found that founders who were able to quickly perform new venture-creation activities were more likely to terminate the pursuit of their potential opportunities (Brush et al., 2008).

\section{Promoting New Venture Legitimacy}

New ventures suffer from the liabilities of newness. Founders need to establish legitimacy for their new ventures to enhance new venture performance. New venture legitimacy refers to audiences' assessments that a new venture and its actions are desirable, acceptable, and appropriate. Founders attempt to achieve legitimacy for their new ventures by seeking endorsement, promoting legitimacy, and securing human and financial capital.

First, founders often seek some form of endorsement to increase new venture legitimacy. Potential stakeholders are typically uncertain about a new venture. Founders can reduce potential stakeholders' uncertainty over their new ventures by signaling the ventures' quality and credibility to external audiences. For example, founders can build new venture 
legitimacy by highlighting their experience. The benefits of experience in establishing new venture legitimacy are magnified when a new venture can gain third-party endorsements and third-party affiliations. Indeed, one study found that positive signals - namely, having a founder with managerial experience, having at least one product in the market, and operating from a commercial property-are more impactful for raising external funding when a new venture affiliates with an incubator (Plummer et al., 2016).

Similarly, new ventures can establish legitimacy through several mechanisms: (1) identity mechanisms affect how a venture is portrayed to others to enhance its legitimacy, (2) associative mechanisms establish legitimacy through communicating a new venture's link to other entities, and (3) organizational mechanisms communicate a new venture's attributes and achievements (Fisher et al., 2017). For example, these mechanisms can lead to certification. Certification occurs when an authoritative or high-status entity formally acknowledges that a new venture has met current standards. This certification can help the founder transition the new venture from a plan to an operational venture, particularly in low-legitimacy sectors.

Second, as implied above, founders can influence new venture legitimacy. Founders seek legitimacy for their new ventures by (1) establishing what matters to them based on their values and beliefs, $(2)$ focusing attention on what matters to their audiences, and (3) finding a balance between what matters to them and what matters to their new ventures' potential stakeholders. Therefore, founders need to reflect on themselves and their potential stakeholders to engage in legitimacy work targeted at their audiences' expectations but only in a way in which the founders do not feel like they have overly compromised their values and beliefs.

Also, (potential) stakeholders judge a new venture more favorably when it communicates a legitimately distinctive identity. New ventures communicate their identities through legitimizing claims (i.e., aligning ventures with institutional rules and expectations) and distinctiveness claims (i.e., meaningfully distancing ventures from institutional rules and expectations). The appropriate balance of legitimizing and distinctiveness claims depends on the environment. For example, when entering a new market, founders' are likely to emphasize distinctiveness from established markets. In contrast, when new ventures need legitimacy (more than distinctiveness), founders are likely to highlight their credentials (including their education, experience, and status) to signal to potential 
stakeholders that their new ventures align with norms and stakeholder expectations. Founders can also increase audiences' positive evaluations of their new ventures by engaging in impression management to communicate certain aspects of their new ventures to (potential) stakeholders and disguise others. However, some efforts to establish legitimacy may break moral codes, such as when founders tell legitimacy lies. Founders tell legitimacy lies when they intentionally misrepresent the facts about their new ventures to deceive (potential) stakeholders.

Third, legitimacy can impact access to human capital, which is of critical importance to new ventures. New ventures can attract potential employees by finding the right balance between distinctive-employment claims (e.g., a highly innovative work environment) and new venturelegitimacy claims. In a study of job seekers, founders' claims about their new ventures' distinctiveness were more important than claims about these ventures' legitimacy in attracting employees to work for new ventures (Moser et al., 2017). More specifically, this study showed that highly innovative employees are attracted to new ventures that have a distinct ideology - committed to a cause-and new ventures with highly legitimate founders (i.e., founders who were educated at a prestigious university and had professional experience at a renowned firm) (Moser et al., 2017).

Finally, establishing new venture legitimacy involves a process over time. This process is dynamic and entails a new venture's status and reputation. Reputation is an economic concept reflecting past performance that signals quality and merit. Status is a sociological concept of social rank that signals privilege. A new venture can build its status through its reputation (more so for older firms and through big hits [e.g., a blockbuster initial public offering for venture capital firms]) (Pollock et al., 2015). Moreover, a new venture's current status can influence its future status (in a path-dependent or imprinting way) but less so the older the venture. Similarly, a new venture's first partner's reputation has an immediate and ongoing impact on the venture's status. A critical element of establishing a new venture's legitimacy is enrolling stakeholders to commit resources to the new venture. Stakeholder enrollment is the process by which founders (and new ventures) develop and strengthen their psychological bonds with (potential) stakeholders. 


\section{Founder Exit}

Founder exit refers to when an individual involved in creating a venture leaves the role of owner/manager of that venture. Founders have different exit strategies and modes of exit.

First, there is heterogeneity in the likelihood of founder exit. Founder exit is more likely to occur in older and larger ventures. As ventures age and grow, their tasks shift from more entrepreneurial tasks to more managerial tasks. Given this shift in the nature of new venture tasks, replacing a founder with a professional manager can benefit a venture. Some founder exits are forced upon founders by investors/owners. Founders are less likely to be forced to exit their ventures when they had success at their previous firms, had prior relationships with the other founding team members (i.e., before starting their ventures), and have prior startup experience. High environmental uncertainty magnifies these founder-persistence effects.

Counterintuitively, there is a founders' dilemma in which founders who are most successful in growing their new ventures are those who are most likely to be replaced by stockholders. This dilemma is explained by the fact that success in growing a new venture increases the venture's reliance on external funding. These equity investors acquire greater ownership in the venture and use this control to replace the founder with a professional manager. Generally, founder-CEOs are more likely to be replaced when their ventures perform either among the worst or the best in their respective industries. Therefore, the mismatch between the focal business's quality and its founder's ability drives founder displacement. Interestingly, while ventures that replace their founder-CEOs are more likely to fail, those that survive grow faster and have more positive investor reactions at their initial public offerings. Indeed, when investors replace founders with professional managers, venture performance typically increases.

Second, founders may choose to exit their ventures voluntarily. Founders may voluntarily exit their ventures for several reasons. For example, founders may voluntarily exit to avoid racking up additional personal losses (i.e., overcome the bias that causes founders to be reluctant to exit their ventures despite a losing course of action). Founders also voluntarily exit their ventures when they become frustrated by losing control over their ventures' direction. Therefore, founder exit can be full 
(exit management and ownership) or partial (exit management or ownership). For example, some founders may have a harvest strategy whereby they voluntarily exit their ventures to "pull money" out of their ventures based on the value they have created.

\section{Starting New Ventures in Different Environments}

A new venture's external environment is the context beyond the boundaries of the emergent venture. The external environment can impact a new venture through its imprinting effect. This imprinting effect differs depending on the specific environmental dimensions and the government influences of the environmental context.

First, the external environment can imprint new ventures. Imprinting explains how founders and ventures develop characteristics based on venture creation that persist despite environmental changes. Founders can be imprinted by their (1) families and friends to pursue multiple unrelated ventures, (2) hobbies to focus on user communities to make product or service improvements without a primary focus on financial rewards, or (3) prior work experience to focus on markets and industries expected to be important (see Chapter 1). Moreover, the initial mode of organizing can have a persistent impact on a new venture. For example, founders who initially engage in organizational knowledge brokeringeffectively transferring knowledge from one technical field to innovate in another technical field-can enhance the benefits of search for new venture performance (Hsu \& Lim, 2013). The masculinity or femininity of the industry in which a founder creates a new venture can also imprint on the new venture. For example, new ventures based on female-identity claims in a male-dominated industry can face the liability of differentiation (Micelotta et al., 2018). The liability of differentiation is the disadvantage of a new venture offering a gender identity different from the gender of competitors and the focal industry.

Second, the different dimensions of the environment can have different influences on new venture creation and performance. New ventures are more innovative in more competitive and munificent environments and in environments that are less manufacturing intensive and with a smaller market size. New digital technologies can also influence new venture creation through several enabling mechanisms that impact the new venture-creation process. Differences in the external environment can also occur across countries. For example, the benefits of founders' 
resources for starting a new venture are magnified in countries that have a more entrepreneurially oriented financial system, a more established educational system, and a culture that is more trusting but less hierarchal and less communal (De Clercq et al., 2013). A country's culture is less hierarchical when its citizens lack a strong desire for the power-structure status quo and is less communal when its citizens perceive themselves as autonomous.

Finally, the government can influence a new venture's context. One study in Israel found that government subsidies for research and development seemed to stimulate external investment, foster innovation, and improve the likelihood of new firm survival (Conti, 2018). Another form of subsidy is the government providing advice, education, and other information to founders and their new ventures. While governments can provide an environment in which founders and their new ventures can benefit, governments can also "throw sand in the wheels of efficiency." For example, to access resources and services from governments, founders may feel obliged to pay bribes to government officials to receive those resources or services promptly. The payment of these bribes is an illegal activity. A study in China found that nascent entrepreneurs are more likely to offer bribes to government officials when the local economic conditions are declining, especially entrepreneurs who see themselves as underdogs (Baron et al., 2018). An underdog identity refers to founders' beliefs that members of society perceive them as low in social status and that it is difficult to change society's perception of them.

\section{CONCLUSION}

New venture creation-namely, the phenomenon of starting a new organization - is at the core of the field of entrepreneurship and is also informative to the broader field of management. The literature on new venture creation has rapidly evolved in the past two decades. Hence, in this chapter, we described how entrepreneurs move through the stages of co-creating, organizing, and performing startups. The summarizing model in Fig. 5.1 suggests the following:

- During the co-creating stage, the cognitions and social relationships of lead founders or founding teams shape how they acquire stakeholders and build communities of inquiry to start exploiting new business opportunities. 
- During the organizing stage, lead founders or founding teams develop processes for engaging in activities and improving operational effectiveness. They craft strategies and develop their ventures' business models.

- During the performing stage, lead founders or founding teams execute on their ventures' strategies to scale the ventures, which includes enhancing the ventures' legitimacy and, potentially, replacing founders.

- Ventures' external environment shapes the processes of co-creating, organizing, and performing through imprinting lead founders or founding teams and setting the boundaries, including industry characteristics, access to resources, and institutional frameworks.

\section{REFERENCES}

Baron, R. A., Hmieleski, K. M., \& Henry, R. A. (2012). Entrepreneurs' dispositional positive affect: The potential benefits-And potential costs-Of being "up." Journal of Business Venturing, 27(3), 310-324.

Baron, R. A., \& Tang, J. (2011). The role of entrepreneurs in firm-level innovation: Joint effects of positive affect, creativity, and environmental dynamism. Journal of Business Venturing, 26(1), 49-60.

Baron, R. A., Tang, J., Tang, Z., \& Zhang, Y. (2018). Bribes as entrepreneurial actions: Why underdog entrepreneurs feel compelled to use them. Journal of Business Venturing, 33(6), 679-690.

Baum, J. R., \& Bird, B. J. (2010). The successful intelligence of high-growth entrepreneurs: Links to new venture growth. Organization Science, 21(2), 397-412.

Beckman, C. M. (2006). The influence of founding team company affiliations on firm behavior. Academy of Management Journal, 49(4), 741-758.

Beckman, C. M., Schoonhoven, C. B., Rottner, R. M., \& Kim, S. J. (2014). Relational pluralism in de novo organizations: Boards of directors as bridges or barriers to diverse alliance portfolios? Academy of Management Journal, $57(2), 460-483$.

Brigham, K. H., De Castro, J. O., \& Shepherd, D. A. (2007). A personorganization fit model of owner-managers' cognitive style and organizational demands. Entrepreneurship Theory and Practice, 31(1), 29-51.

Brush, C. G., Manolova, T. S., \& Edelman, L. F. (2008). Properties of emerging organizations: An empirical test. Journal of Business Venturing, 23(5), 547566.

Campbell, B. A., Ganco, M., Franco, A. M., \& Agarwal, R. (2012). Who leaves, where to, and why worry? Employee mobility, entrepreneurship and effects on source firm performance. Strategic Management Journal, 33(1), 65-87. 
Carnahan, S., Agarwal, R., \& Campbell, B. A. (2012). Heterogeneity in turnover: The effect of relative compensation dispersion of firms on the mobility and entrepreneurship of extreme performers. Strategic Management Journal, 22(12), 1411-1430.

Conti, A. (2018). Entrepreneurial finance and the effects of restrictions on government R\&D subsidies. Organization Science, 29(1), 134-153.

De Clercq, D., Lim, D. S., \& Oh, C. H. (2013). Individual-level resources and new business activity: The contingent role of institutional context. Entrepreneurship Theory and Practice, 37(2), 303-330.

Edelman, L. F., Manolova, T., Shirokova, G., \& Tsukanova, T. (2016). The impact of family support on young entrepreneurs' startup activities. Journal of Business Venturing, 31(4), 428-448.

Eesley, C. E., Hsu, D. H., \& Roberts, E. B. (2014). The contingent effects of top management teams on venture performance: Aligning founding team composition with innovation strategy and commercialization environment. Strategic Management Journal, 35(12), 1798-1817.

Farmer, S. M., Yao, X., \& Kung-Mcintyre, K. (2011). The behavioral impact of entrepreneur identity aspiration and prior entrepreneurial experience. Entrepreneurship Theory and Practice, 35(2), 245-273.

Fauchart, E., \& Gruber, M. (2011). Darwinians, communitarians, and missionaries: The role of founder identity in entrepreneurship. Academy of Management Journal, 54(5), 935-957.

Fisher, G., Kuratko, D. F., Bloodgood, J. M., \& Hornsby, J. S. (2017). Legitimate to whom? The challenge of audience diversity and new venture legitimacy. Journal of Business Venturing, 32(1), 52-71.

Franke, N., Gruber, M., Harhoff, D., \& Henkel, J. (2006). What you are is what you like-Similarity biases in venture capitalists' evaluations of startup teams. Journal of Business Venturing, 21(6), 802-826.

Ganco, M. (2013). Cutting the Gordian knot: The effect of knowledge complexity on employee mobility and entrepreneurship. Strategic Management Journal, 34(6), 666-686.

Gielnik, M. M., Barabas, S., Frese, M., Namatovu-Dawa, R., Scholz, F. A., Metzger, J. R., \& Walter, T. (2014). A temporal analysis of how entrepreneurial goal intentions, positive fantasies, and action planning affect starting a new venture and when the effects wear off. Journal of Business Venturing, 29(6), 755-772.

Greul, A., West, J., \& Bock, S. (2018). Open at birth? Why new firms do (or don't) use open innovation. Strategic Entrepreneurship Journal, 12(3), 392420 .

Hoogendoorn, S., Parker, S. C., \& Van Praag, M. (2017). Smart or diverse startup teams? Evidence from a field experiment. Organization Science, 28(6), 1010-1028. 
Hsu, D. H., \& Lim, K. (2013). Knowledge brokering and organizational innovation: Founder imprinting effects. Organization Science, 25(4), 1134-1153. Hyytinen, A., Pajarinen, M., \& Rouvinen, P. (2015). Does innovativeness reduce startup survival rates? Journal of Business Venturing, 30(4), 564-581.

Katz, J., \& Gartner, W. B. (1988). Properties of emerging organizations. Academy of Management Review, 13(3), 429-441.

Kickul, J., Gundry, L. K., Barbosa, S. D., \& Whitcanack, L. (2009). Intuition versus analysis? Testing differential models of cognitive style on entrepreneurial self-efficacy and the new venture creation process. Entrepreneurship Theory and Practice, 33(2), 439-453.

Kier, A. S., \& McMullen, J. S. (2018). Entrepreneurial imaginativeness in new venture ideation. Academy of Management Journal, 61(6), 2265-2295.

Lichtenstein, B. B., Dooley, K. J., \& Lumpkin, G. T. (2006). Measuring emergence in the dynamics of new venture creation. Journal of Business Venturing, 21(2), 153-175.

Ling, Y., Zhao, H., \& Baron, R. A. (2007). Influence of founder-CEOs’ personal values on firm performance: Moderating effects of firm age and size. Journal of Management, 33(5), 673-696.

Micelotta, E., Washington, M., \& Docekalova, I. (2018). Industry gender imprinting and new venture creation: The liabilities of women's leagues in the sports industry. Entrepreneurship Theory and Practice, 42(1), 94-128.

Moser, K. J., Tumasjan, A., \& Welpe, I. M. (2017). Small but attractive: Dimensions of new venture employer attractiveness and the moderating role of applicants' entrepreneurial behaviors. Journal of Business Venturing, 32(5), 588-610.

Mueller, S., Volery, T., \& Von Siemens, B. (2012). What do entrepreneurs actually do? An observational study of entrepreneurs' everyday behavior in the start-up and growth stages. Entrepreneurship Theory and Practice, 36(5), 995-1017.

Murnieks, C. Y., Cardon, M. S., Sudek, R., White, T. D., \& Brooks, W. T. (2016). Drawn to the fire: The role of passion, tenacity and inspirational leadership in angel investing. Journal of Business Venturing, 31(4), 468-484.

Peterson, S. J., Walumbwa, F. O., Byron, K., \& Myrowitz, J. (2009). CEO positive psychological traits, transformational leadership, and firm performance in high-technology startup and established firms. Journal of Management, 35(2), 348-368.

Plummer, L. A., Allison, T. H., \& Connelly, B. L. (2016). Better together? Signaling interactions in new venture pursuit of initial external capital. Academy of Management Journal, 59(5), 1585-1604.

Pollock, T. G., Lee, P. M., Jin, K., \& Lashley, K. (2015). (Un)tangled: Exploring the asymmetric coevolution of new venture capital firms' reputation and status. Administrative Science Quarterly, 60(3), 482-517. 
Qin, F., Wright, M., \& Gao, J. (2017). Are 'sea turtles' slower? Returnee entrepreneurs, venture resources and speed of entrepreneurial entry. Journal of Business Venturing, 32(6), 694-706.

Sarasvathy, S. D. (2001). Causation and effectuation: Toward a theoretical shift from economic inevitability to entrepreneurial contingency. Academy of Management Review, 26(2), 243-263.

Shepherd, D. A., Souitaris, V., \& Gruber, M. (2021). Creating new ventures: A review and research agenda. Journal of Management, 47(1), 11-42.

Souitaris, V., Zerbinati, S., \& Al-Laham, A. (2007). Do entrepreneurship programmes raise entrepreneurial intentions of science and engineering students? The effects of learning, inspiration and resources. Journal of Business Venturing, 22(4), 566-591.

Tanriverdi, H., \& Lee, C. H. (2008). Within-industry diversification and firm performance in the presence of network externalities: Evidence from the software industry. Academy of Management Journal, 51(2), 381-397.

Uy, M. A., Foo, M. D., \& Song, Z. (2013). Joint effects of prior start-up experience and coping strategies on entrepreneurs' psychological well-being. Journal of Business Venturing, 28(5), 583-597.

Walske, J. M., \& Zacharakis, A. (2009). Genetically engineered: Why some venture capital firms are more successful than others. Entrepreneurship Theory and Practice, 33(1), 297-318.

Zheng, Y. (2012). Unlocking founding team prior shared experience: A transactive memory system perspective. Journal of Business Venturing, 27(5), 577-591.

Open Access This chapter is licensed under the terms of the Creative Commons Attribution 4.0 International License (http://creativecommons.org/licenses/ by $/ 4.0 /)$, which permits use, sharing, adaptation, distribution and reproduction in any medium or format, as long as you give appropriate credit to the original author(s) and the source, provide a link to the Creative Commons license and indicate if changes were made.

The images or other third party material in this chapter are included in the chapter's Creative Commons license, unless indicated otherwise in a credit line to the material. If material is not included in the chapter's Creative Commons license and your intended use is not permitted by statutory regulation or exceeds the permitted use, you will need to obtain permission directly from the copyright holder.

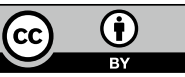

